\title{
Correlations between Parental Attachment, Conflictual Independence from Parents and Career Attitude Maturity in Associate and Bachelor Nursing Students
}

\author{
Kyung-soon Jeong ${ }^{1} \cdot \mathrm{Ji}^{-}$Young $\mathrm{Han}^{2}$
}

College of Nursing, Department of Nursing, Kimcheon Science College, Associate Professor ${ }^{1}$

Department of Nursing Silla University, Assistant Professor ${ }^{2}$

\section{$=$ Abstract $=$ \\ 간호대학생의 부모에 대한 애착, 독립에 대한 갈등 및 직업에 대한 태도성숙의 관계}

\author{
정 경 순 $^{1} \cdot$ 한 지 영 ${ }^{2}$
}

\section{김천과학대학교 간호학과 ${ }^{1}$, 신라대학교 간호학과 ${ }^{2}$}

\begin{abstract}
목 적: 이 연구의 목적은 졸업예정자인 3,4 년제 간호대학생의 부모에 대한 애착, 독립에 대한 갈등, 그리고 직업에 대한 태도성숙의 관계를 알아보기 위함이다.

방 법: 본 연구는 3 개의 시에 있는 1 개의 3 년제와 2 개의 4 년제 대학에 재학 중인 3,4 학년 간호대학생을 대상으로 편의표집하였다. 자료수집은 대상자에게 직접 설명한 후 동의를 거쳐 구조화된 설문지에 각자 기 입하도록 하였으며, 수집된 총 200부의 질문지 중 불성실한 답변을 제외한 190부(3년제 113부, 4년제 77 부)를 최종분석에 사용하였다. 자료수집은 2010년 4월 26일부터 6월 30일 사이에 이루어졌다. Armsden \& Greenberg (1987)의 도구를 이용하여 부모에 대한 애착을 측정하였으며 Hoffman (1984)의 도구로 독립에 대한 갈등을, Lee 등(1991)의 도구로 직업에 대한 태도성숙을 측정하였다. 수집된 자료는 SPSS 20.0 program을 이용하여 분석하였다.

결 과: 부모에 대한 애착, 독립에 대한 갈등 및 직업에 대한 태도성숙의 3 영역 모두에서 4년제 간호대학생 이 3 년제 간호대학생보다 평균점수가 높게 나타났으며, 부모에 대한 애착, 독립에 대한 갈등 그리고 직업에 대한 태도성숙 간에는 정적 상관관계가 있는 것으로 나타났다.
\end{abstract}

결 론: 본 연구결과 간호대학생의 직업에 대한 태도성숙은 부모와의 애착관계와 독립에 대한 갈등과 상관관 계가 있는 것으로 나타나, 직업에 대한 태도성숙을 향상시키기 위해서는 부모와의 관계에 대한 이해가 우선 적으로 이루어져야함을 제시하였다.

Key Words: 간호대학생, 부모에 대한 애착, 독립에 대한 갈등, 직업에 대한 태도성숙

\section{Introduction}

교신저자: 한지영, 부산광역시 사상구 백양대로 700 번길 신라대학교 간호학과

전화번호: 051-999-5872, 팩스번호: 051-999-5176

E-mail: hanjy@silla.ac.kr

원고접수: 2012년 11월 7일, 원고채택: 2012년 12월 10일
A number of researchers have empirically investigated the relationship between family interaction patterns and career development 
- Kyung-soon Jeong - Ji-Young Han: Correlations between Parental Attachment, Conflictual Independence from Parents and Career Attitude Maturity in Associate and Bachelor Nursing Students -

and have reported some evidence for idea that parents have an influence on the career development process of young adult (Lee \& Hughey, 2001). Collectivistic cultures tend to foster mutually dependent familial relationships, thus the advice of parents has an impact on career choice. Parents provided not only a source of identification for their career development, but also guided them to formulate feelings about occupation. Parents are invested in their children's career development and children seek help from parents for career information, developmental support, and decision-making assistance (Kim \& Lee, 2007).

Secure attachment has been positively associated with various dimensions of social and emotional well-being in late adolescent college students (Armsden \& Greenberg, 1987; Kenny, 1987; Kenny \& Hart, 1992). Characteristics of secure parental attachment have been associated empirically with indices of adaptive social and psychological functioning across a variety of developmental periods (Kenny \& Barton, 2002). Among college students, secure parental attachments have been positively associated with college adjustment, assertiveness in social relationships, enhanced resources for coping with stress, and career exploration and commitment (Larose \& Boivin, 1997; Kenny, 1987; Brack, Gay, \& Matheny, 1993; Blustein, Walbridge, Friedlander, \& Palladino, 1991). Several studies have examined the relationship between psychological separation and attachment. Attachments to parents and psychological separation both have been found to be related to healthy functioning and adjustment in college students (Armsden \& Greenberg, 1987; Rice, FitzGerald,
Whaley, \& Gibbs, 1995; Vivona, 2000). On the other hand, impaired psychological separation from parents has been related to psychological symptoms of distress and difficulty with personal adjustment in a college population (Lucas, 1997; Rice et al., 1995).

From the point of view of psychoanalysis, then, the psychological separation of late adolescents from their parents is thought to be an important developmental task affecting both personality organization and personal adjustment. Psychological separation from parents has positive relationship with career attitude maturity, and is a significant influence for the career development (Lee, 2006; Kim, 2000).

In order to attain successful personal adjustment, the adolescent must separate psychologically from both parents while maintaining positive family ties (Hoffman, 1984). Conflictual Independence from parents has consistently associated with progress in career commitment and has highly significant effects on dysfunctional career thought (Blustein, Walbridge, Friedlander, \& Palladino, 1991; Lee, 2006; Koh, \& Kang, 2003). Conflictual independence is a subscale of defined psychological separation and refers to freedom from excessive guilt, anxiety, mistrust, responsibility, inhibition, resentment, and anger in relation to the parents (Hoffman, 1984).

Attachment and conflictual independence are to be seen not as opposite but as complementary forces involved in the same process. A successful separation implies maintenance of connectedness with parents (Geuzaine, Debry, \& Liesens, 2000). Parental attachment and conflictual independence from parents have significant effects on career attitude maturity (Lee, 
2002; Lee, 2006; Kim, 2000).

Career attitude maturity is central to a developmental approach to understanding career behavior and involves an assessment of an individual's level of career progress in relation to his or her career-relevant development tasks (Crites, 1976). Students with relatively high levels of career attitude maturity are confident in their ability to make good decisions, and plan appropriately regarding academic and experimental options related to their chosen goals (Steven, Alberto, \& Paul, 2000). Also, career attitude maturity has significant negative relationship with employment stress and cognitive emotion. Crites's (1978) model of career attitude maturity proposed that it consists of affective and cognitive dimensions. The cognitive dimension is composed of decision-making skills; the affective dimension includes attitudes toward the career decision-making process. To improve career attitude maturity, it is necessary to pay attention to parental attachment and conflictual independence from parents.

To date, no studies have investigated both conflictual independence from parents and parental attachment in relation to the career attitude maturity for nursing students. In order to more fully understand the role of parents relative to career development of nursing students, both conflictual independence and attachment must be taken into account.

The purpose of this study was conducted to investigate the relationship between parental attachment, conflictual independence from parents and career attitude maturity in associate and bachelor nursing students.

\section{Methods}

\section{Design and Participants}

This study was a descriptive survey design, which identified the relationship between the conflictual independence from parents, parental attachment and career attitude maturity in associate and bachelor nursing students. The study was conducted using a convenient sampling method from three universities in three cities.

The purpose of the study was explained to the students and the participation in the study was completely voluntary. The participants were given a complete guarantee of confidentiality and provided informed consent prior to $\mathrm{com}^{-}$ pleting the survey packet. The total time required for the questionnaire's completion was $10 \mathrm{~min}$. In determining the appropriate sample size, medium effect was chosen based on G* POWER 3.1 (Erdfelder, Faul \& Buchner, 1996). Using an alpha of .05 and power of the significance test set at level .80 $(\beta=.20) \quad$ (Cohen, 1988), a sample of at least 128 subjects (64 associate degree in nursing (ADN) students, 64 bachelor of science in nursing (BSN) students) was necessary to keep risks of statistical errors to standard levels for calculating multiple regression. The final sample size $(n=190)$ provided the requirement for performing this research (113 associate course students, 77 bachelor course students). Total sample of 200 students was obtained for the study, of which 190 stu- $^{-}$ dents completed the questionnaires used for the analysis. Data were collected from April 26, 2010 to June 30, 2010. 
- Kyung-soon Jeong - Ji-Young Han: Correlations between Parental Attachment, Conflictual Independence from Parents and Career Attitude Maturity in Associate and Bachelor Nursing Students -

\section{Instruments}

Data were collected through self-reported questionnaires that were included conflictual independence from parents, parental attachment and career attitude maturity scale.

\section{1) Parental attachment}

Parental attachment was measured using the scale originally developed by Armsden \& Greenberg (1987), which is translated by Jung (1994). The three scales, based on factors analysis, are trust, communication, and alienation. Participants respond to the 28 items but the participant is asked to answer the questions twice (once for mother and once for father). Participants respond to items along a five-point Likert continuum from almost true or always true to almost never or never true that describes their relationship with and feelings toward their parent. In addition to the three subscales for parent, it can be scored for overall quality of attachment relations by summing the raw scores for trust and communication and subtracting the alienation score. Jung (1994) reported Cronbach's a .88 (mother) and .91 (father). In this study, Cronbach's a of scale was .92 (mother) and .91 (father).

\section{2) Conflictual independence from parents}

Conflictual Independence was measured using the scale originally developed by Hoffman (1984), which is modified by Shin (2000). Conflictual Independence refers to freedom from guilt, anxiety, mistrust, and responsibility toward or resentment of parents. Items are rated on a 5 -point Likert scale ranging from 1 (almost never or never true), to 5 (almost always or always true). Shin (2000) reported Cronbach's a .90 (mother), and .94 (father). In the present sample, the Cronbach's a .89 (mother), and .90 (father).

\section{3) Career attitude maturity}

Career attitude maturity (Lee, 1997) was measured using a 47 item questionnaire, with a 5-point Likert scare, Which was adapted from the career attitude maturity inventory (CMI) of Crites (1978). It was composed 5 subscales: decisiveness (10 items), preparation (10 items), independence (9 items), goal-orientation (8 items), confidence (10 items).

Each items was scored on a 5-point Likert scale ranging from 1 (not at all) to 5 (very much). Mean scores of each subscale were obtained by summing all scores and dividing by the number of items per scale. Higher the score means greater the career attitude maturity. Lee and Han (1997) reported Cronbach's a decisiveness .88 , preparation .76 , independence .75 , goal-orientation 75 , and confidence .75 . In the present sample, Cronbach's a of scale was .89 (decisiveness .88, preparation .80, independence .66, goal-orientation 80 , and confidence .87).

\section{Data Analysis}

Data were analyzed using SPSS 20.0 program and the level of significance was set at .05 for all tests. Data were summarized using descriptive statistics (mean, standard deviation, frequency, and percentage). Comparison of general characteristics, parental attachment, conflictual inde- 
pendence from parents, and career attitude maturity in associate and bachelor nursing students were analyzed by $t-$ test, $\chi^{2}$ test, and analysis of variance (ANOVA).

Pearson correlation analyzed the relationships between parental attachment, conflictual independence from parents, and career attitude maturity. Cronbach's alpha coefficients were calculated for instrument's reliability.

\section{Results}

\section{General Characteristics in Subjects}

General characteristics of the participants are presented in Table 1. Age of subject ranged from 20 to 31 (mean $21.76 \pm 1.70$ ). bachelor nursing students (mean 22.22 \pm 1.74 ) were higher than associate nursing students (mean 21.44 \pm 1.74 ). For gender of subject, there were more female students (88.4\%) compare to male students (11.6\%). There were no significant differences between associate and bachelor nursing students in parents education and monthly income. In parents education, high school graduate was highest. $87.6 \%$ of associate nursing students were living together with their parents whereas $45.5 \%$ of bachelor nursing students were living together with their parents.

\begin{tabular}{|c|c|c|c|c|c|}
\hline \multirow[b]{2}{*}{ Characteristics } & & \multicolumn{2}{|c|}{$\mathrm{N}(\%)$} & \multirow[b]{2}{*}{$\chi^{2} / t$} & \multirow[b]{2}{*}{$\mathrm{p}$} \\
\hline & & $\begin{array}{c}\mathrm{ADN} \\
(\mathrm{n}=113)\end{array}$ & $\begin{array}{c}\text { BSN } \\
(n=77)\end{array}$ & & \\
\hline \multirow[t]{4}{*}{ Age(yr) } & 20 & $28(24.8)$ & - & 58.54 & $<.001$ \\
\hline & 22 & $6(5.3)$ & $37(48.0)$ & & \\
\hline & $\geq 23$ & $23(20.4)$ & $13(16.9)$ & & \\
\hline & $\mathrm{M} \pm \mathrm{SD}$ & $21.44 \pm 1.59$ & $22.22 \pm 1.74$ & -3.18 & .002 \\
\hline \multirow[t]{2}{*}{ Gender } & Female & $92(81.4)$ & $76(98.7)$ & 13.36 & $<.001$ \\
\hline & Male & $21(18.6)$ & $1(1.3)$ & & \\
\hline \multirow[t]{4}{*}{ Father's education } & Elementary school & $4(3.5)$ & $1(1.3)$ & 1.91 & .592 \\
\hline & Middle school & $15(13.3)$ & $7(9.2)$ & & \\
\hline & High school & $72(63.7)$ & $51(66.1)$ & & \\
\hline & College & $22(19.5)$ & $18(23.4)$ & & \\
\hline \multirow[t]{4}{*}{ Mother's education } & Elementary school & $3(2.7)$ & $4(5.2)$ & 2.54 & .469 \\
\hline & Middle school & $11(9.7)$ & $4(5.2)$ & & \\
\hline & High school & 67 (59.3) & $43(55.8)$ & & \\
\hline & College & $32(28.3)$ & $26(33.8)$ & & \\
\hline \multirow[t]{4}{*}{ Monthly Income } & $\leq 2,000,000$ won & $19(17.0)$ & $10(13.0)$ & 2.57 & .632 \\
\hline & $\leq 3,000,000$ won & $38(33.9)$ & $25(32.5)$ & & \\
\hline & $\leq 5,000,000$ won & $40(35.7)$ & $29(37.6)$ & & \\
\hline & $>5,000,000$ won & $15(13.4)$ & $13(16.9)$ & & \\
\hline \multirow[t]{2}{*}{ Cohabitation } & Cohabitation & $99(87.6)$ & $35(45.5)$ & 46.55 & $<.001$ \\
\hline & Separation & $14(12.4)$ & $42(54.5)$ & & \\
\hline
\end{tabular}

Abbreviations: ADN, associate degree in nursing; BSN, bachelor of science in nursing 
- Kyung-soon Jeong - Ji-Young Han: Correlations between Parental Attachment, Conflictual Independence from Parents and Career Attitude Maturity in Associate and Bachelor Nursing Students -

2. Parental attachment, Conflictual independence from parents, and Career attitude maturity behavior by general characteristics

Table 2 showed differences in variables ac- cording to general characteristic. There were no significant differences in age, parents education and income. On education system, bachelor nursing students showed significantly higher level of parental attachment, conflictual independence,

Table 2. Differences in Variables According to General Characteristics

$(\mathrm{N}=190)$

\begin{tabular}{|c|c|c|c|c|c|c|}
\hline \multirow{3}{*}{ Characteristics } & \multirow{3}{*}{ Categories } & \multicolumn{2}{|c|}{ Attachment } & \multicolumn{2}{|c|}{ Conflictual independence } & \multirow{2}{*}{$\begin{array}{c}\text { Career } \\
\text { attitude } \\
\text { maturity }\end{array}$} \\
\hline & & Father & Mother & Father & Mother & \\
\hline & & $\mathrm{M} \pm \mathrm{SD}$ & $\mathrm{M} \pm \mathrm{SD}$ & $\mathrm{M} \pm \mathrm{SD}$ & $\mathrm{M} \pm \mathrm{SD}$ & $\mathrm{M} \pm \mathrm{SD}$ \\
\hline \multirow[t]{6}{*}{$\mathrm{Yr}$} & 20 & $53.64 \pm 15.46$ & $55.93 \pm 14.71$ & $3.78 \pm .71$ & $3.82 \pm .64$ & $3.52 \pm .46$ \\
\hline & 21 & $53.05 \pm 16.74$ & $56.88 \pm 16.43$ & $3.59 \pm .63$ & $3.67 \pm .59$ & $3.59 \pm .424$ \\
\hline & 22 & $58.63 \pm 13.74$ & $62.07 \pm 14.97$ & $3.81 \pm .60$ & $3.85 \pm .54$ & $3.59 \pm .39$ \\
\hline & $\geq 23$ & $53.80 \pm 18.00$ & $56.17 \pm 16.65$ & $3.67 \pm .76$ & $3.66 \pm .73$ & $3.59 \pm .41$ \\
\hline & $\mathrm{F}$ & 1.148 & 1.355 & 1.188 & 1.148 & .201 \\
\hline & $\mathrm{p}$ & .331 & .258 & .316 & .331 & .897 \\
\hline \multirow[t]{4}{*}{$\mathrm{M} / \mathrm{F}$} & Male & $47.35 \pm 20.36$ & $51.41 \pm 18.80$ & $3.54 \pm .89$ & $3.55 \pm .81$ & $3.59 \pm .44$ \\
\hline & Female & $55.43 \pm 15.45$ & $58.61 \pm 15.41$ & $3.70 \pm .63$ & $3.76 \pm .59$ & $3.58 \pm .42$ \\
\hline & $\mathrm{t}$ & -2.248 & -2.005 & -1.006 & -1.496 & .056 \\
\hline & $\mathrm{p}$ & .035 & .046 & .316 & .136 & .955 \\
\hline \multirow[t]{4}{*}{ Education } & College & $51.42 \pm 16.15$ & $54.85 \pm 15.40$ & $3.60 \pm .66$ & $3.66 \pm .61$ & $3.52 \pm .45$ \\
\hline & University & $59.21 \pm 15.22$ & $62.03 \pm 15.89$ & $3.81 \pm .66$ & $3.84 \pm .63$ & $3.67 \pm .36$ \\
\hline & $\mathrm{t}$ & -3.261 & -3.091 & -2.152 & -2.025 & -2.415 \\
\hline & $\mathrm{p}$ & .001 & .002 & .033 & .044 & .017 \\
\hline \multirow{6}{*}{$\begin{array}{l}\text { Father's } \\
\text { education }\end{array}$} & Elementary school & $62.33 \pm 14.81$ & $53.57 \pm 19.56$ & $3.98 \pm .61$ & $3.94 \pm .52$ & $3.62 \pm .33$ \\
\hline & Middle school & $54.00 \pm 11.67$ & $57.14 \pm 9.40$ & $3.65 \pm .51$ & $3.74 \pm .38$ & $3.41 \pm .36$ \\
\hline & High school & $53.32 \pm 17.03$ & $57.27 \pm 16.44$ & $3.64 \pm .69$ & $3.70 \pm .67$ & $3.63 \pm .44$ \\
\hline & College & $56.16 \pm 15.66$ & $59.34 \pm 16.06$ & $3.74 \pm .65$ & $3.77 \pm .59$ & $3.53 \pm .40$ \\
\hline & $\mathrm{F}$ & .853 & .389 & .643 & .441 & 1.561 \\
\hline & $\mathrm{p}$ & .467 & .761 & .588 & .724 & .200 \\
\hline \multirow{6}{*}{$\begin{array}{l}\text { Mother's } \\
\text { education }\end{array}$} & Elementary school & $54.60 \pm 16.41$ & $55.20 \pm 16.39$ & $3.81 \pm .76$ & $3.79 \pm .71$ & $3.63 \pm .30$ \\
\hline & Middle school & $53.90 \pm 15.43$ & $57.45 \pm 13.41$ & $3.57 \pm .73$ & $3.67 \pm .64$ & $3.52 \pm .46$ \\
\hline & High school & $54.43 \pm 16.12$ & $56.89 \pm 16.25$ & $3.69 \pm .62$ & $3.71 \pm .60$ & $3.60 \pm .39$ \\
\hline & College & $55.08 \pm 17.58$ & $61.08 \pm 16.45$ & $3.69 \pm .77$ & $3.83 \pm .65$ & $3.55 \pm .51$ \\
\hline & $\mathrm{F}$ & .025 & .710 & .262 & .444 & .279 \\
\hline & $\mathrm{p}$ & .994 & .547 & .853 & .722 & .841 \\
\hline \multirow{6}{*}{$\begin{array}{l}\text { Income } \\
\text { (million won) }\end{array}$} & $1 \sim 2$ & $52.52 \pm 17.87$ & $56.22 \pm 16.58$ & $3.63 \pm .73$ & $3.71 \pm .58$ & $3.47 \pm .55$ \\
\hline & $2 \sim 3$ & $54.29 \pm 16.39$ & $58.05 \pm 16.07$ & $3.67 \pm .71$ & $3.77 \pm .67$ & $3.60 \pm .43$ \\
\hline & $3 \sim 5$ & $56.07 \pm 15.70$ & $59.32 \pm 15.04$ & $3.68 \pm .66$ & $3.66 \pm .68$ & $3.60 \pm .34$ \\
\hline & More than 5 & $54.00 \pm 15.71$ & $54.79 \pm 17.56$ & $3.80 \pm .51$ & $3.76 \pm .56$ & $3.61 \pm .44$ \\
\hline & $\mathrm{F}$ & .345 & .631 & .378 & .173 & .791 \\
\hline & $\mathrm{p}$ & .793 & .596 & .769 & .915 & .501 \\
\hline \multirow[t]{4}{*}{ Cohabitation } & Cohabitation & $53.45 \pm 16.16$ & $56.83 \pm 15.85$ & $3.64 \pm .66$ & $3.68 \pm .65$ & $3.58 \pm .44$ \\
\hline & Separation & $58.86 \pm 15.09$ & $61.27 \pm 15.13$ & $3.81 \pm .66$ & $3.84 \pm .60$ & $3.60 \pm .37$ \\
\hline & $\mathrm{t}$ & -2.030 & -1.733 & -1.507 & -1.497 & -.235 \\
\hline & $\mathrm{p}$ & .044 & .085 & .134 & .136 & .814 \\
\hline
\end{tabular}


and career attitude maturity than those of associate nursing students.

3. The level of parental attachment, conflictual independence from parents, and career attitude maturity in associate and bachelor nursing students

Table 3 presents the means and standard deviations of parental attachment, conflictual independence from parents, and career attitude maturity in associate and bachelor nursing students. In attachment to father, the mean score of bachelor nursing students showed significantly higher score than that of associate nursing students $(t=-3.261, p=.001)$. It was $59.21( \pm 15.22)$ in associate nursing students and $51.42( \pm 16.15)$ in bachelor nursing students. In attachment to mother, the mean score of bachelor nursing students showed also significantly higher score than that of associate nursing students $(t=$ -3.091, $\mathrm{p}=.002)$. It was 62.03 $( \pm 15.89)$ in associate nursing students and for 54.85 ( \pm 15.40) in associate nursing students. Bachelor nursing students scored significantly higher on the conflictual independence from father $(t=$ -2.152, $\mathrm{p}=.033)$ and mother $(\mathrm{t}=-2.025, \mathrm{p}=$ .044). Bachelor nursing students also had the highest score in the decisiveness $(t=-2.357, p=$ .019) and goal-orientation ( $\mathrm{t}=-3,377, \mathrm{p}=.001)$ of career attitude maturity with mean scores that were significantly higher than that of associate nursing students.

4. The correlations of parental attachment, conflictual independence from parents, and career attitude maturity in associate and bachelor nursing students

Table 4 reported the correlation matrix of

Table 3. Mean Score for Parental Attachment, Conflictual Independence and Career Maturity

\begin{tabular}{|c|c|c|c|c|c|c|}
\hline \multirow[t]{2}{*}{ Variables } & & $\begin{array}{c}\text { ADN } \\
(n=113)\end{array}$ & $\begin{array}{c}\mathrm{BSN} \\
(\mathrm{n}=77)\end{array}$ & $\begin{array}{c}\text { Total } \\
(n=190)\end{array}$ & \multirow[t]{2}{*}{$\mathrm{t}$} & \multirow[t]{2}{*}{$\mathrm{p}$} \\
\hline & & $\mathrm{M} \pm \mathrm{SD}$ & $\mathrm{M} \pm \mathrm{SD}$ & $\mathrm{M} \pm \mathrm{SD}$ & & \\
\hline \multirow{4}{*}{$\begin{array}{l}\text { Attachment to } \\
\text { father }\end{array}$} & Trust & $36.88 \pm 6.83$ & $40.40 \pm 5.93$ & $38.30 \pm 6.69$ & -3.586 & $<.001$ \\
\hline & Communication & $34.24 \pm 5.41$ & $36.23 \pm 5.77$ & $35.03 \pm 5.63$ & -2.373 & .019 \\
\hline & Alienation & $19.70 \pm 5.77$ & $17.42 \pm 5.38$ & $18.79 \pm 5.71$ & 2.273 & .008 \\
\hline & Total & $51.42 \pm 16.15$ & $59.21 \pm 15.22$ & $54.54 \pm 16.20$ & -3.261 & .001 \\
\hline \multirow{4}{*}{$\begin{array}{l}\text { Attachment of } \\
\text { mother }\end{array}$} & Trust & $38.40 \pm 6.24$ & $41.67 \pm 5.84$ & $39.73 \pm 6.28$ & -3.616 & $<.001$ \\
\hline & Communication & $36.02 \pm 4.96$ & $37.74 \pm 6.12$ & $36.72 \pm 5.54$ & -2.105 & .037 \\
\hline & Alienation & $19.57 \pm 6.11$ & $17.38 \pm 5.41$ & $18.68 \pm 5.92$ & 2.515 & .013 \\
\hline & Total & $54.85 \pm 15.40$ & $62.03 \pm 15.89$ & $57.76 \pm 15.96$ & -3.091 & .002 \\
\hline \multirow{2}{*}{$\begin{array}{l}\text { Conflictual } \\
\text { independence }\end{array}$} & Father & $3.60 \pm .66$ & $3.81 \pm .66$ & $3.69 \pm .66$ & -2.152 & .033 \\
\hline & Mother & $3.66 \pm .61$ & $3.84 \pm .63$ & $3.73 \pm .62$ & -2.025 & .044 \\
\hline \multirow[t]{6}{*}{ Career maturity } & Decisiveness & $3.67 \pm .76$ & $3.93 \pm .72$ & $3.78 \pm .75$ & -2.357 & .019 \\
\hline & Preparation & $4.02 \pm .60$ & $4.16 \pm .46$ & $4.08 \pm .54$ & -1.746 & .082 \\
\hline & Independence & $3.63 \pm .80$ & $3.61 \pm .61$ & $3.60 \pm .64$ & .163 & .871 \\
\hline & Goal-orientation & $2.86 \pm .66$ & $3.17 \pm .53$ & $2.98 \pm .63$ & -3.377 & .001 \\
\hline & Confidence & $3.41 \pm .67$ & $3.46 \pm .69$ & $3.43 \pm .68$ & -.564 & .573 \\
\hline & Total & $3.52 \pm .45$ & $3.67 \pm .36$ & $3.58 \pm .42$ & -2.522 & .017 \\
\hline
\end{tabular}

Abbreviations: ADN, associate degree in nursing; BSN, bachelor of science in nursing 
- Kyung-soon Jeong - Ji-Young Han: Correlations between Parental Attachment, Conflictual Independence from Parents and Career Attitude Maturity in Associate and Bachelor Nursing Students -

parental attachment, conflictual independence from parents, and career attitude maturity in associate and bachelor nursing students. Career attitude maturity in associate nursing students showed a significantly positive correlation between parental attachment (father $\mathrm{r}=384$, $\mathrm{p}<.001$, mother $\mathrm{r}=305, \mathrm{p}<.001$ ), and conflictual independence from parents (father $\mathrm{r}=375, \mathrm{p}<.001$, mother $\mathrm{r}=323, \mathrm{p}<.001)$. In associate nursing students, Conflictual independence from father was the most positively correlated with Conflictual independence from mother $(r=.900, p<.001)$.

Career attitude maturity in bachelor nursing students reported significant positive relationships with attachment to mother $(r=.263, p=$
.022) and conflictual independence from mother $(\mathrm{r}=.266, \mathrm{p}=.020)$. In bachelor nursing students, Conflictual independence from father was also the most positively correlated with Conflictual independence from mother $(r=.883, p<.001)$. Attachment to father and onflictual independence from mother did not report a statistical significance in correlation analysis with career attitude maturity.

Career attitude maturity in total participants showed a significantly positive correlation between parental attachment (father $\mathrm{r}=353, \mathrm{p}<.001$, mother $\mathrm{r}=315, \mathrm{p}<.001$ ), and conflictual independence from parents (father $\mathrm{r}=335, \mathrm{p}<.001$, mother $r=318, p<.001)$.

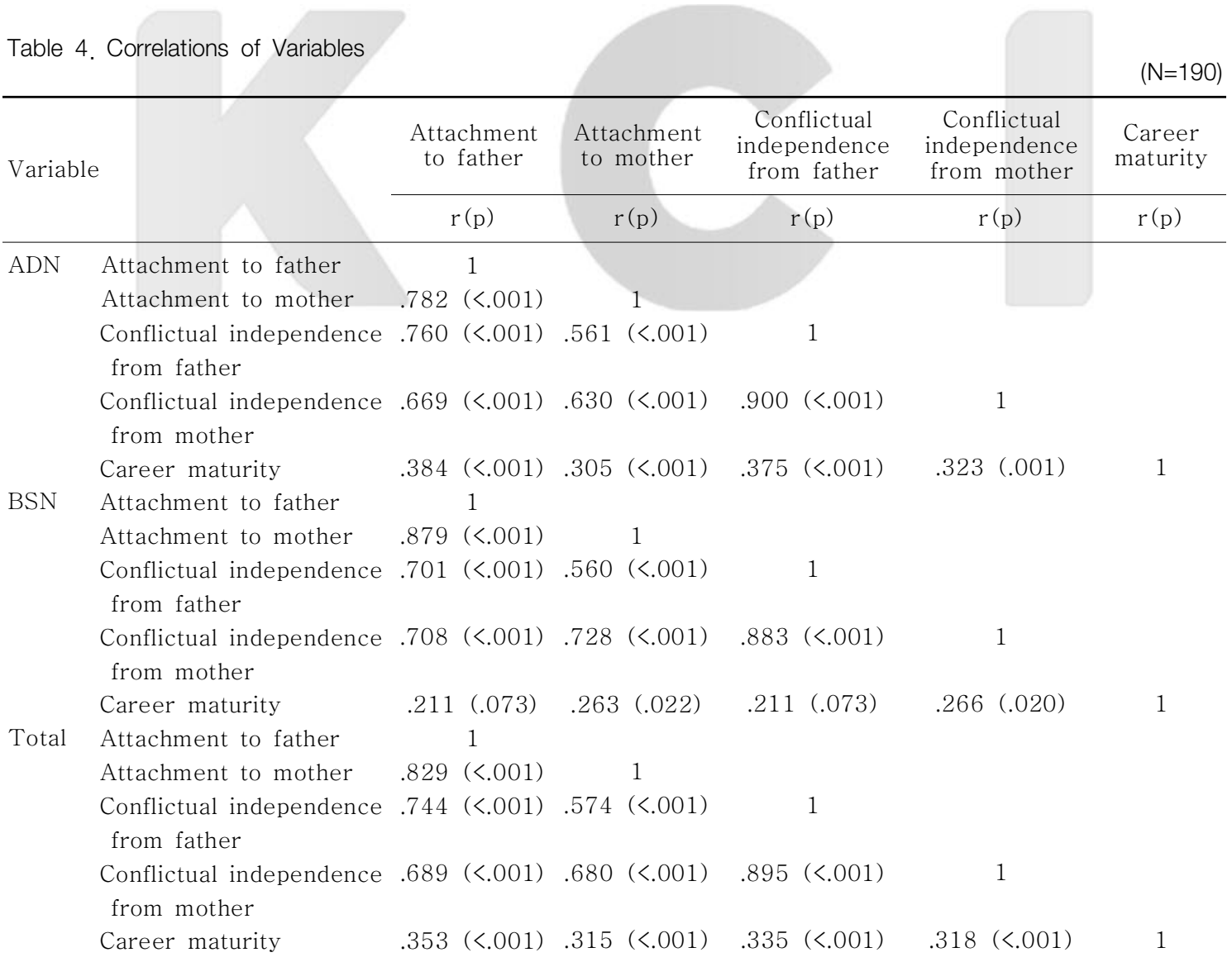

Abbreviations: ADN, associate degree in nursing; BSN, bachelor of science in nursing 


\section{Discussion}

Recent study has investigated on the role and importance of the separation process of young adults from their parents and its affect on career exploration (O'Brien, Friedman, Tipton, \& Linn, 2000; Vivona, 2000). This study examined the correlations between parental attachment, conflictual independence from parents and career attitude maturity in associate and bachelor nursing students.

In this research the level of parental attachment were 54.54 (father) and 57.76 (mother). This result was higher similar to previous studies (Schwartz \& Buboltz, 2004; Kim \& Cheon, 2001). The average of women's parental attachment was significantly higher than that of men. the participants in the present study were almost women, limiting the generalization of the results. Also, parental attachment in bachelor students were higher than that of associate students. This is thought to be related to educational environment and the collectivistic cultures.

Regarding average conflictual independence from parents was 3.69 (father) and 3.73 (mother), which was higher than similar study reported by Song \& Park (2006). It was no statistically significant difference in general characteristics except education system. Conflictual independence from parents in bachelor students were higher than that of associate students.

In the present study, the mean of career attitude maturity was 3.58; Subcategory is decisiveness 3.78 , preparation 4.08 , independence 3.60, goal-orientation 2.98, and confidence 3.43. This result was similar to the study by Lee $\&$
Lim (2011) and was higher than the study by Lim et al. (2010) and This finding may associated with the typology of career decision status, because most of the nursing students are determined career. Regarding Subcategory of career attitude maturity, the level bachelor nursing students were higher than that of associate nursing students in decisiveness, goal-orientation, while there were not the significant difference in preparation, independence and confidence in associate and bachelor nursing students. It remains unclear whether the education environment can be affected these findings. Thus, it is necessary to evaluate the effect of education environment by conducting a follow-up.

A statistically significant positive correlation was observed between parental attachment, conflictual independence from parents, and career attitude maturity in participants.

The correlation between parental attachment and conflictual independence from parents was significantly positive in associate and bachelor nursing students. This result supports the previous research(Blustein et al., 1991; Kenny, 1990; Ryan et al., 1996). Blustein et al. (1991) reported the combination of psychological separation and parental attachment made the most significant contribution to progress in committing to career choice and Leondari \& Kiosseoglou (2000) found that the high-security group obtained significantly higher scores on the conflictual independence than the low-security group.

Concerning career attitude maturity, associate nursing students had significantly positive correlations with parental attachment and conflictual independence from parents, while bachelor nursing students had significantly positive correla- 
- Kyung-soon Jeong - Ji-Young Han: Correlations between Parental Attachment, Conflictual Independence from Parents and Career Attitude Maturity in Associate and Bachelor Nursing Students -

tions with attachment to mother and conflictual independence from mother. These findings are similiar to the previous studies (Armsden \& Greenberg, 1987; Kenny, 1987; Kenny \& Donaldson, 1991). Shim \& Kang (2007) showed that the most effective variable on career decision making level is the attachment level to mother and Kenny (1990) reported the perception of parental attachment and its influence on career attitude maturity for college students. Based upon the results of these studies, it appears that parental attachment is positively related to the development of individual career attitude maturity.

This study showed that career attitude maturity of associate nursing students was positively correlated with conflictual independence from parents, while career attitude maturity of bachelor nursing students was only positive correlation with conflictual independence from mother. These findings are in accordance with those of previous studies (Lee, 2006; Koh, \& Kang, 2003) in which the higher the degree of conflictual independence, the lower the degree of dysfunctional career thinking. But some researchers suggested that conflictual independence from parents was not significantly associated with career attitude maturity (Lee \& Hughey, 2001; Thomason \& Winer, 1994). However the results have not been consistent. Therefore, additional studies should seek to replicate these findings. Differences in the results could be attributed to differences in the participants. Thus, characteristics of participants must be taken into consideration.

In conclusion, relationships with parental attachment, conflictual independence from parents and career attitude maturity are very strong, good relationships with their parents should be taken into consideration in promoting career attitude maturity in nursing students.

The study discussed here has limitations. First, participants were from a convenient nonrandom sample that may not be representative of the population. Second, the majority of participants were attending 3 universities in 3 cities, limiting the generalizability of the results. Therefore, additional studies should seek to replicate these findings as well as examine other factors which impact nursing students' career attitude maturity.

\section{Conclusions}

Our study provides conflictual independence from parents and parental attachment were positively correlated with the career attitude maturity in associate and bechelor nursing students. This finding might reflect the importance of $\mathrm{pa}^{-}$ rental attachment and conflictual independence from parents and show that this understanding helps promote career attitude maturity in nursing students.

The findings are important in extending (a) the understanding of relationship parental attachment, conflictual independence from parents, and career attitude maturity in nursing students and (b) the understanding of the influencing factor on career attitude maturity. Derived from the understandings of the factors influencing career attitude maturity, various career development strategies for nursing students should be developed to be focused on parental attachment and conflictual independence from parents. 


\section{References}

Armsden GC, Greenberg MT. (). The inventory of parent and peer attachment: Individual differences and their relationship to psychological well-being in adolescence. Journal of Youth and Adolescence 1987; $16: 427-454$

Blustein DL, Walbridge MM, Friedlander ML, Palladino DE. Contributions of psychological separation and parental attachment to the career development process. Journal of Counseling Psychology 1991; 38:39-50

Brack G, Gay MF, Matheny KB. Relationships between attachment and coping resources among late adolescents. Journal of College Student Development 1993;34:212-215

Crites JO. The Career Maturity Inventory. In D. E. Super (Ed.), Measuring vocational maturity for counseling and evaluation [Monograph]. Washington, DC: National Vocational Guidance Association. 1974

Crites JO. Theory and research handbook for the Career Maturity Inventory (2nd ed.). Monterey, CA: McGraw-Hill. 1978

Erdfelder E, Faul F, Buchner A. GPOWER: A general power analysis program, Behavior Research $\mathrm{Me}^{-}$ thods, Instrument \& Computer 1996;28(1):1-11

Geuzaine C, Debry M, Liesens V. Separation from parents in late adolescence: The same for boys and girls?. Journal of Youth and Adolescence 2000;29(1):79-91

Hoffman JA, Weiss B. Family dynamics and presenting problems in college students. Journal of Counseling Psychology 1987;34:157-163

Jung JS. The relationship among Self identity, independence, and attachment [dissertation]. Graduate School of Korea University, 1994

Kenny ME. The extent and function of parental attachment among first-year college students. Journal of Youth and Adolescence 1987;16:17-27

Kenny ME. College senior's perceptions of parental attachment: The value and stability of family ties. Journal of College Student Development 1990;31: $39-46$

Kenny ME, Barton C. Attachment theory and research: Contributions for understanding late adolescent and young adult development. In J. Demick \& C. Andreoletti(Eds.), Handbook of adult development (371-389). Norwell, MA: Kluwer. 2002

Kenny ME, Hart K. Relationship between parental attachment and eating disorders in an inpatient and a college sample. Journal of Counseling Psychology 1992;39:521-526

Kenny ME, Donaldson GA. Contributions of parental attachment and family structure to the social and psychological functioning of first-year college students. Journal of Counseling Psychology 1991; 38:479-486

Kim HJ. Effect of college student's ego-identity on vocational attitude maturity and preparation behavior. Social Science Research 2001;5:369-393

Kim SJ. The relationship between types of career development and psychological separation of $\mathrm{col}^{-}$ lege student[dissertation]. Graduate School of Seoul National University, 2000

Kim SL, Lee JC. Influence of parent support, career decision-making self-efficacy and dysfunctional career thoughts on adolescent career maturity. Korean Journal of Counseling and Psychotherapy 2007;19:393-407

Kim UJ, Cheon SM. The effect of conflictual independence from parents and parental attachment on the college students' career decision status. The Korean Journal of East West Mind Science 2001;4(1):147-162

Koh HJ, Kang HW. The relationship between psychological independence from parents and dysfunctional career thinking. The Korean Journal of Counseling and Psychotherapy 2003;15(2):277293

Larose S, Boivin M. Structural relations among attachment working models of parents, general and specific support expectations, and personal adjustment in late adolescence. Journal of Social and Personal Relationships 1997;14:579-601

Lee GH, Han JC. A study on validity of career attitude tool. The Journal of Career Educational Research 1997;8:219-255

Lee HY, Hughey KF. The relationship of psychological separation and parental attachment to the career maturity of college freshman from intact families. Journal of Career Development 2001;27 (4) :279-293

Lee JH, Lim ST. The moderating effects of college 
- Kyung-soon Jeong - Ji-Young Han: Correlations between Parental Attachment, Conflictual Independence from Parents and Career Attitude Maturity in Associate and Bachelor Nursing Students -

students' career maturity on the relations between satisfaction of major and career stress. The $\mathrm{JO}^{-}$ urnal of vocational Education Research 2011;30 (3) : $133-146$

Lee KM. The relationship among paental attachment psychological independence from parent and dysfunctional career thoughts [dissertation]. Graduate School of Hongik University, 2006

Leondari A, Kiosseoglou G. The relationship of parental attachment and psychological separation to the psychological functioning of young adults. The Journal of Social Psychology 2000;140(4):451464

Lim JY, Kim MA, Kim SY, Kim EJ, Lee JE, Ko YK. The effects of a cognitive-behavioral therapy on career attitude maturity, decision making style, and self-esteem of nursing students in Korea. Nurse Education Today 2010;30(8):731-736

Lucas M. Identity development, career development, and psychological separation from parents: Similarities and differences between men and women. Journal of Counseling Psychology 1997;44:123132

O'Brien KM, Friedman SM, Tipton LC, Linn SG. Attachment, separation and women's vocational development: A longitudinal analysis. Journal of Counseling Psychology 2000;47:301-315

Rice KG, FitzGerald DP, Whaley TJ, Gibbs CL. Crosssectional and longitudinal examination of attachment, separation-individuation, and college student adjustment. Journal of Counseling and Development 1995;73:463-474
Ryan NE., Solberg VS, Brown SD. Family dysfunction, parental attachment, and career search self-efficacy among community college students. Journal of Counseling Psychology 1996;43:84-89

Shim HK, Kang MH. The effect of attachment to parents on career decision-making self-efficacy, career aspiration and career decision-making level among college students. Journal of Psychotherapy 2007;7(1):1-17

Shin JY. The relation of psychological separation from parents, family cohesion and adjustment to college[dissertation]. Graduate School of Yonsei University, 2000

Schwartz JP, Buboltz WC. The relationship between attachment to parents and psychological separation in college students. Journal of College Student Development 2004;45(5):566-577

Song S, Park HI. Empirical study on the psychological separation from their parents of university students. Journal of Parents Education Research 2006;3(2):5-25

Steven RP, Alberto FC, Paul V. Career Maturity and College Student Persistence. Journal of College Student Retention 2000;1 (1):41-58

Thomason SL, Winer JL. Career maturity and familial independence among college -freshman. Journal of Career Development 1994;21:23-35

Vivona JM. Parental attachment styles of late adolescents: Qualities of attachment relationships and consequences for adjustment. Journal of $\mathrm{Co}^{-}$ unseling Psychology 2000; 47:316-329 